\title{
The Clic-MD software a tool to analyze thousands of data in seconds: trends of climate and agro climatic indices
}

\section{El software Clic-MD es una herramienta para analizar miles de datos en segundos: tendencias del clima e índices agroclimáticos}

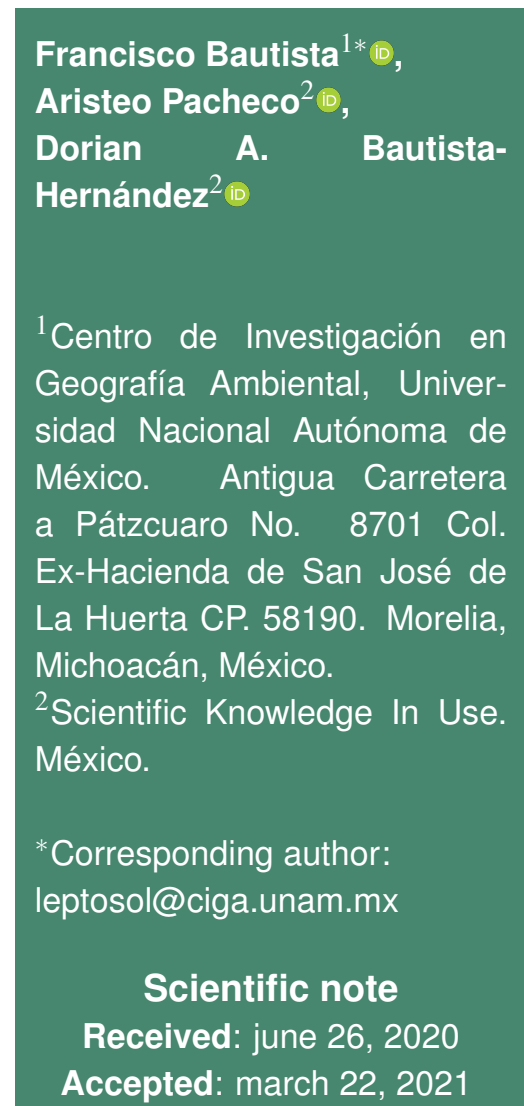

How to cite: Bautista F, Pacheco A, BautistaHernández DA (2021) The Clic-MD software a tool to analyze thousands of data in seconds: trends of climate and agro climatic indices. Ecosistemas y Recursos Agropecuarios 8(1): e2637. DOI: 10.19136/era.a8n1.2637
ABSTRACT. The analysis of climate data is tedious and time-consuming, delaying the analysis of millions of meteorological data worldwide. Local level decision making about climate change requires converting data into information. The aim was to develop software to analyze thousands of meteorological data in seconds. We first designed the database, selected the statistical tests used in time series analyses, and chose agroclimatic indexes, before designing the algorithms. Finally, we developed the software having in mind its easiness of use, and its efficiency for processing data and interpreting results. The software was tested several times by potential users, which allowed improvements in the development and design of the software. Clic-MD includes a set of routines for calculating derived variables most used in land evaluation such as agroclimatic indices, probability of rainfall by month, and others. Clic-MD allows for identifying climate change trends (climate anomalies and extreme events).

Key words: Climate change, climatic anomalies, extreme events, maximum temperature, minimum temperature.

RESUMEN. El análisis de los datos climáticos es tedioso y lento, lo que retrasa el análisis de millones de datos meteorológicos en todo el mundo. La toma de decisiones a nivel local sobre el cambio climático requiere convertir los datos en información. El objetivo fue desarrollar un software para analizar miles de datos meteorológicos en segundos. Diseñamos la base de datos, seleccionamos las pruebas para el análisis de las series de tiempo y los índices agroclimáticos. Desarrollamos el software teniendo en cuenta su facilidad de uso y su eficiencia para procesar datos e interpretar resultados. El software fue probado varias veces por usuarios potenciales. Clic-MD incluye un conjunto de rutinas para calcular las variables derivadas más utilizadas en la evaluación de la tierra, como los índices agroclimáticos, la probabilidad de lluvia por mes y otras. Clic-MD permite identificar las tendencias del cambio climático (anomalías climáticas y eventos extremos).

Palabras clave: Cambio climático, anomalías climáticas, eventos extremos, temperatura máxima, temperatura mínima. 


\section{INTRODUCTION}

Climate change is a global concern for all areas of life, but especially for cropping (Villers et al. 2009, Montiel-González et al. 2019, Ortega et al. 2019, Montiel-González et al. 2021) and livestock farming (Monterroso et al. 2011), biodiversity conservation and ecosystems management (Archer and Predick 2008), and human health. A climate change discourse at the global level has been well understood and disseminated, however, there is little understanding about the magnitude and direction of local climate change (Bautista et al. 2013). Consequently, this global discourse is applied to explain local effects of climate change, an approach that is not always appropriate. Since mitigation and adaptation actions against the adverse effects of climate change need to be implemented at the local level, knowledge about current local situations derived from local scale data is urgently need for either anticipating potential issues or for taking advantage of the opportunities created by climate change.

While most countries, states and municipalities are designing public policy strategies to cope with climate change (Lioubimtseva and Henebry 2009), local information is needed for appropriate planning and for answering some basic questions (Montiel-González et al. 2019, Ortega et al. 2019): When analyzing available historical meteorological data, are we observing climate change or only normal variations in climate? Of what kind (pulsed or gradual) and in which direction (warming or cooling) is the climate change we observe? What is the magnitude, period of occurrence, and location of climate change? (Del Río et al. 2011, Jain et al. 2013, López-Diáz et al. 2013).

Analyzing millions of meteorological data is time consuming and carries a high monetary cost. For that reason, software has been created allowing for agile information management, such as CDBm, Moclic (Bautista et al. 2013), and others. However, most of the existing software operates by means of obsolete technology that is no longer compatible with newer hardware or has limited applications (MontielGonzález et al. 2021). The Clic-MD software was created with the aims of: a) identifying trends of climate change and evaluating their magnitude and direction, b) calculating agro climatic indices, c) identifying climatic anomalies or extreme values of climate elements, d) reducing the time needed for data analysis, and e) generating easily interpretable results.

\section{MATERIALS AND METHODS}

\section{Software Design}

Development of the Clic-MD software followed the mexican information technology standards (NMXI-045-NYCE). The waterfall life cycle model was selected for the software. The tools used for software development were: a) Java programming language, which offers platform independence, high performance, and open source; b) the integrated development environment (IDE) Eclipse, used for writing, testing, and debugging of modular crossplatform applications, containing a list of tasks, and its compilation is real-time (Eclipse 2015); and c) the Java based relational database Apache Derby using $2 \mathrm{MB}$ and having JDBC support allowing for embedding Derby into any Java decision structure. The Derby database is easy to install, deploy and use, and the SQL syntax supports client-server mode (Apache 2014). Figure 1 shows the stages, activities and products we followed for development of the software.

The equations were systematized, and we developed a way to access them from the interface. Calculation algorithms were translated to source code. Results are represented in a graphical interface and tabular format. Request functions are executed via the Java-code and SQL.

System requirements for the operation of ClicMD are: $1.0 \mathrm{GHz}$ or higher Intel or AMD processor; $256 \mathrm{MB}$ dedicated RAM memory for optimal performance; VGA screen with a recommended resolution of $1200 \times 800$ and $32 \mathrm{MB}$ of graphics memory for editing or viewing .xls; CD-ROM for installation and a hard drive with $50 \mathrm{Mb}$ of free space for program installation and data; Java Virtual Machine 1.6 or later (JVM); operating systems can be either Microsoft 


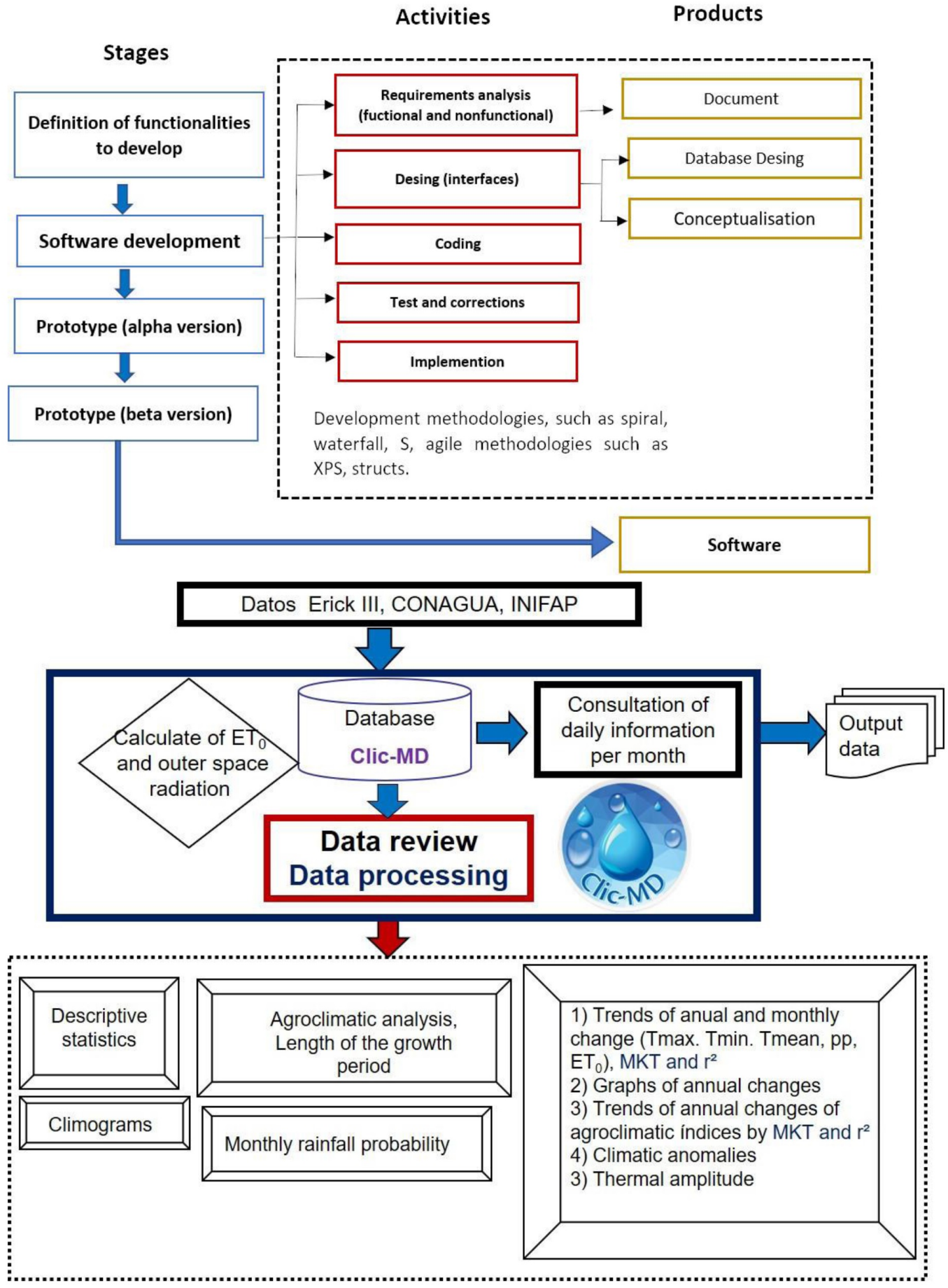

Figure 1. Stages followed for software development and software structure (input data, database, processing, results, and output data).

Windows XP SP3, Windows Vista, Windows 7 or releases above XP and Windows Installer 3.1 or later versions, or any version of Linux and Mac supporting JVN (Cános et al. 2003). 


\section{Data processing}

This software has a set of calculation routines of derived variables which are commonly used in agricultural land evaluation: a) Evapotranspiration (Allen et al. 1998; Bautista et al. 2009); b) Agroclimatic indices (Delgado et al. 2011, Bautista et al. 2011); c) length of the growing period (LPC) (Doorenbos and Pruitt 1977, FAO 1996, Smith 2000, García et al. 2007); d) Monthly rainfall probability (Bautista et al. 2011); e) Plotting of climographs (Orellana et al. 2011); f) Trends of climate change using MannKendall test (MK) and correlation index (Carlón and Mendoza 2007, Bautista et al. 2013); and g) Identification of climatic anomalies and extreme events (Figure 2).

Input data variables are: maximum, average and minimum monthly temperatures, monthly rainfall, and precise geographic location. The subsequent order of calculation is potential evapotranspiration, agroclimatic indices, and trend analyses.

\section{Evapotranspiration}

Estimation of ETO needs the previous calculation of the extraterrestrial radiation ( $\mathrm{Ra}$ ) and the sunshine hours according the geographical position of the weather station. The empirical calculation of evapotranspiration potential (ETO) using the Hargreaves test is performed as follows (Hargreaves and Samani 1985):

$$
E T_{0}=C_{i}\left(t_{\text {med }}-17.78\right)\left(t_{\text {max }}-t_{\text {min }}\right)^{0.5} R a
$$

where: $\mathrm{C}_{i}=0.0023$, a constant; $\mathrm{t}_{\text {med }}=$ medium or average temperature; $\mathrm{t}_{\max }=$ maximum temperature; $\mathrm{t}_{\text {min }}=$ minimum temperature; $\mathrm{Ra}=$ extraterrestrial radiation according to latitude, and is calculated by:

$$
R a=\frac{24(60)}{\pi} G_{s c} d_{r}\left[\omega_{s} \operatorname{sen}(\varphi) \operatorname{sen}(\delta)+\cos (\varphi) \operatorname{sen}(\delta) \operatorname{sen}\left(\omega_{s}\right)\right]
$$

where: $\pi=\mathrm{Pi} ; \mathrm{G}_{s c}=$ Solar constant $(0.082$ $\left.\mathrm{MJm}^{-2} \mathrm{~min}^{-1}\right) ; \mathrm{d}_{r}=$ Inverse relative Earth-Sun distance; $\omega_{s}=$ angle at sunset; $\varphi=$ latitude (rad); $\delta=$ Solar declination.

\section{Agroclimatic indices}

The agroclimatic indices included are: humidity $(\mathrm{HUi})$, aridity $(\mathrm{ARi})$, concentration of precipitation
(PCi), rainfall erosivity or Fournier's modified index (MFi), soil leaching or Arkley's index (Aki), length of growing season (Growing Season, GS) (Delgado et al. 2011, Bautista et al. 2011) (Table 1).

Length of growing period (LPC). LPC is the period of the year when humidity and temperature are suitable for crop production, for example the yearly lapse of time with continuous rain sufficient for agriculture. The agroecological zone includes and integrates the climate aspect in LPC.

LPC is estimated considering the water balance model according to the ratio of rainfall $(P)$ to potential evapotranspiration $\left(\mathrm{Et}_{0}\right)$. If $L P C$ is not limited by temperature $\left(>6.5^{\circ} \mathrm{C}\right)$, the $\mathrm{P} / \mathrm{Et}_{0}$ ratio determines the type of LPC, its beginning, its length, and its termination. LPC ranges from the month when precipitation exceeds half the $\mathrm{ET}_{0}$ until the month when $\mathrm{P}$ is less than half the $\mathrm{ET}_{0}$.

Monthly rainfall probability. The probability model used for the analysis of historical monthly precipitation data is the Gamma function. Adjusting the Gamma function to monthly precipitation records is based on the calculation of the parameters that shape the function (Thom 1958, Bautista et al. 2016).

First an auxiliary variable $A$ needs to be calculated: $A=\operatorname{In} \bar{X}-\left(\frac{1}{N}\right)\left(\sum \operatorname{In} X\right)$,

Where: $\ln \bar{X}=$ natural logarithm of the average of the data, $\mathrm{N}=$ amount of data and $\sum \operatorname{In} X=$ sum of the natural logarithms of the data.

After A is calculated, it is possible to calculate $\alpha=$ alpha and $\beta=$ beta, the two variables that will shape the probability function adjusted to each month's value:

$$
\alpha=\frac{1+\sqrt{1+\frac{3}{4} A}}{4 A}, \beta=\frac{\bar{X}}{\alpha}
$$

Once $\alpha$ and $\beta$ are calculated, the gamma probability function $f(X)$ can be calculated:

$$
f(X) \frac{x^{a-1} \exp \left(-\frac{x}{\beta}\right)}{\beta^{a} \tau(a)}
$$

The area under the curve of this function calculated with its corresponding integral represents the probability to find a lesser or equal value, i.e. the limit value to the right used as reference. For precipitation 


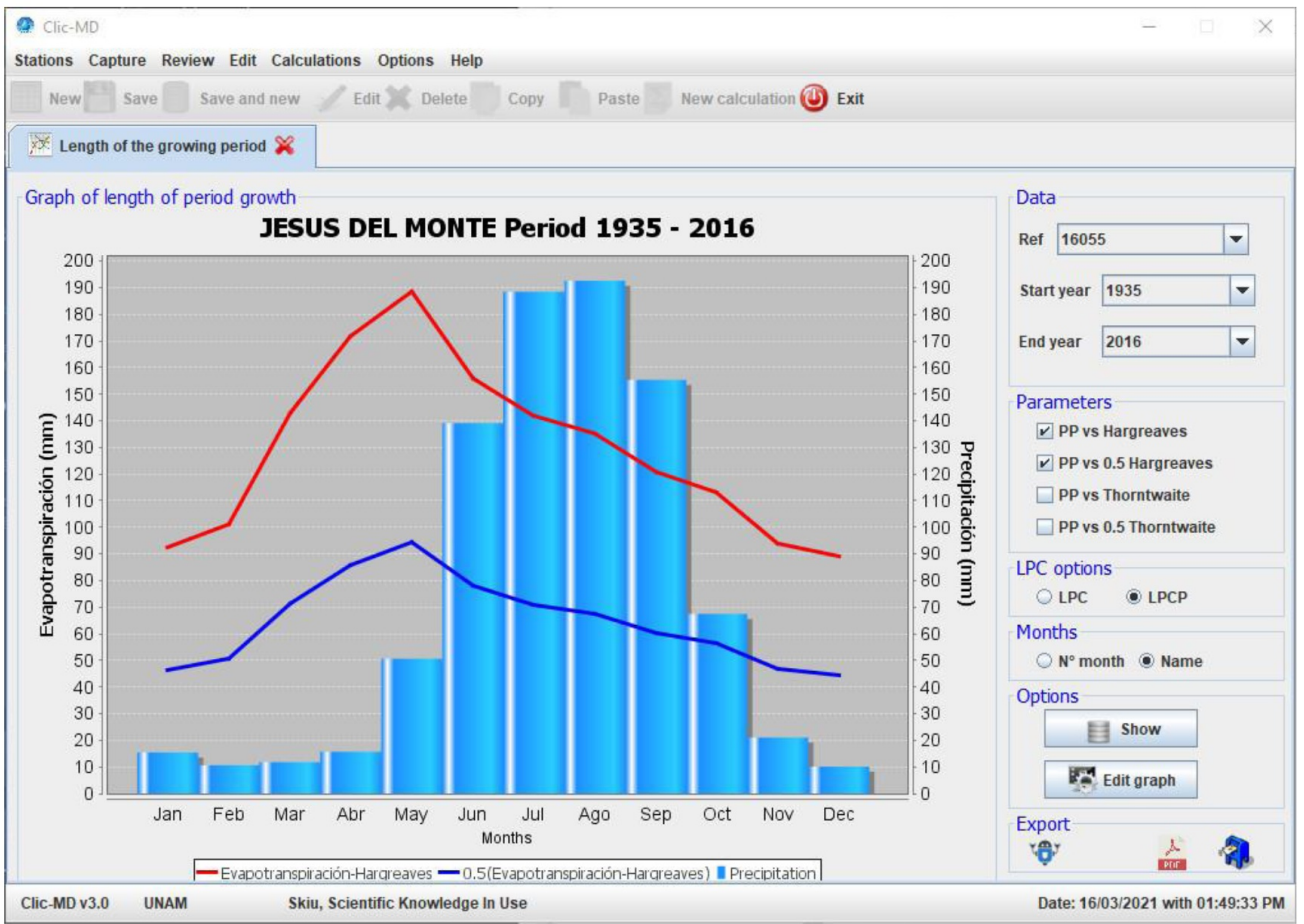

(9) Clic-ML

Stations Capture Review Edit Calculations Options Help

New Save Save and new Edit 2 Delete Copy Paste New calculation (1) Exit

Probability of Rain $\mathscr{\&}$

Graph of probability of rain

JESUS DEL MONTE Period 1935 - 2016 Month: Aug

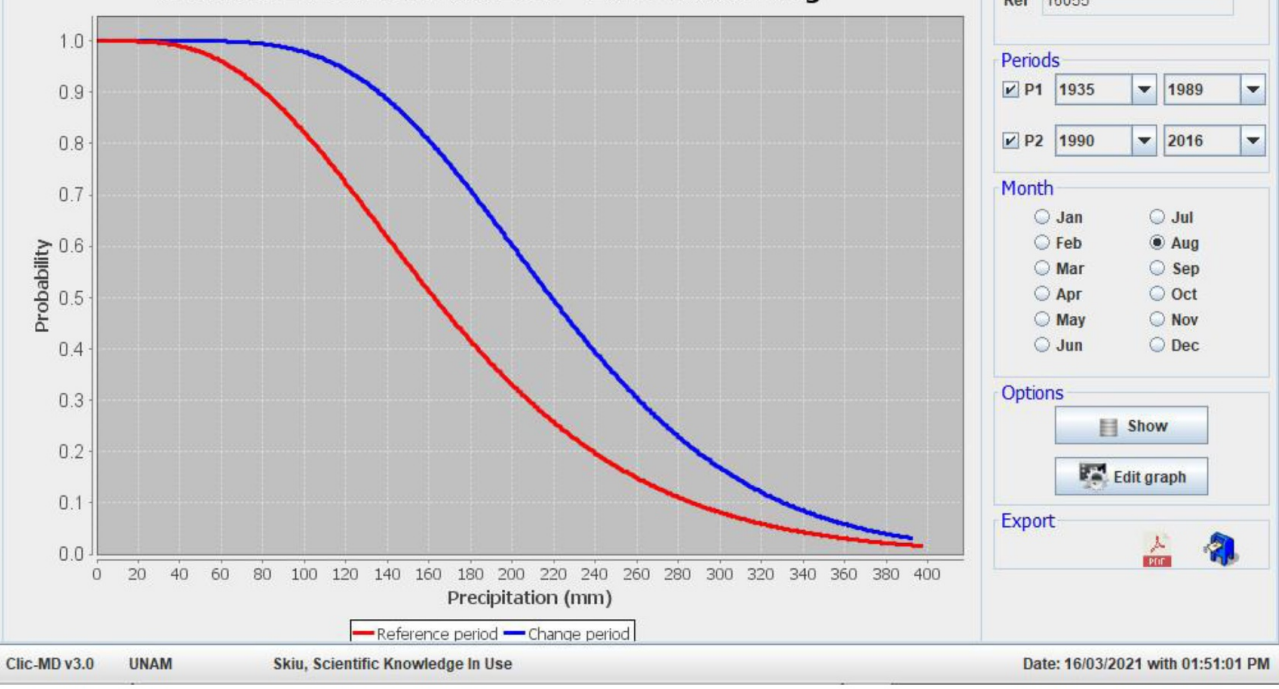

Figure 2. Length of growing period and probability of rain per month for two selected periods.

analysis we need the probability of finding a higher or equal precipitation to each value, so it is necessary to calculate the complement simply obtained by subtracting 1 to each value. 
Table 1. Agroclimatic indices.

$\begin{array}{lll}\text { ARi is the number of months } & \text { GS is the number of months of the } \\ \text { when potential evapotranspiration } & \text { year when the average tempera- } \\ \text { exceeds precipitation. } & \text { ture exceeds } 5{ }^{\circ} \mathrm{C}\end{array}$

Where:

$\mathrm{P}=$ precipitation

$\mathrm{ET}_{0}=$ potential evapotranspiration

AKi is the sum of the monthly

$P C i=100 \times \sum \frac{p^{2}}{P^{2}}$

$M F i=\sum\left(\frac{p^{2}}{P}\right)$

precipitations minus the poten-

tial evapotranspiration value of

those months where precipitation

Where:

Where:

$\mathrm{p}=$ monthly precipitation $\quad \mathrm{p}=$ monthly precipitation

$\mathrm{P}=$ annual precipitation $\quad \mathrm{P}=$ annual precipitation

\section{Climographs}

Climographs are graphical representations of average monthly rainfall in $\mathrm{mm}$ (y-axis) and average monthly temperature in degrees Celsius (y'-axis) (Orellana et al. 2011). According to the Gaussen aridity index (Precipitations in $\mathrm{mm}=$ Temperatures in ${ }^{\circ} \mathrm{C} \times 2$ ), the axis of precipitation is twice the average monthly temperature, therefore showing dry and wet months. In dry months the value of average precipitation is lower than two times the value of average temperature, and higher in wet months.

\section{Trends of temperature and precipitation}

The procedure for the MK test begins by simply comparing the most recent data of the time series with previous values. A score of 1 is given if the latest concentration is larger, or a score of -1 if it is smaller. The total score for the data series is the MK statistic, which is compared against a critical value to verify if data show a trend of change, and if so, if it is an increasing or a decreasing trend (Carlón and Mendoza 2007). The process for the analysis is as follows:

The $\mathrm{n}$ data pairs $\left(\mathrm{x}_{1}, \mathrm{y}_{1}\right),\left(\mathrm{x}_{2}, \mathrm{y}_{2}\right), \ldots\left(\mathrm{x}_{n}, \mathrm{y}_{n}\right)$ are indexed according to the magnitude of the value of $\mathrm{x}$, such that $\mathrm{x}_{1} \leq \mathrm{x}_{2} \leq \ldots \leq \mathrm{x}_{n}$ and $\mathrm{y}_{i}$ is the value of the dependent variable corresponding to $x i$. All $n$ $(n-1) / 2$ ordered pairs of yi values are examined. Let $\mathrm{P}$ be the number of cases where $\mathrm{y}_{i}>\mathrm{y}_{j}(\mathrm{i}>\mathrm{j})$, and let $M$ be the number of cases where $\mathrm{y}_{i}<\mathrm{y}_{j}(\mathrm{i}>\mathrm{j})$. The test statistics is defined by $S=P-M$. For $n>10$, the test is conducted using a normal approximation. The standardized test statistic $Z$ is calculated:

$$
\begin{gathered}
z=\left\{\begin{array}{cc}
\frac{S-1}{\sqrt{\operatorname{Var}(S)}} & S>0 \\
0 & S=0 \\
\frac{S+1}{\sqrt{\operatorname{Var}(S)}} & S<0
\end{array}\right. \\
\operatorname{Var}(S)=n(n-1) \frac{2 n+5}{18}
\end{gathered}
$$

The null hypothesis is rejected at significance level $\alpha$ if $|Z|>Z_{(1-\alpha) / 2}$, where $Z_{(1-\alpha) / 2}$ is the value of the standard normal distribution with a probability of exceedance of $\alpha / 2$. For example, at $\alpha=0.05$ the null hypothesis would be rejected for $|Z|>1.96$. In case some $x$ and/or $y$ values are tied, the formula for $\operatorname{Var}(\mathrm{S})$ is modified. If the sample size is less than 10 , then it is necessary to use tables for the $S$ statistic.

The Kendall correlation coefficient $\tau$ is defined as: $\tau=\frac{S}{\frac{n(n-1)}{2}}$

As with other types of correlation coefficients, $\tau$ can only take values between -1 and 1 , its sign indicating the sign of the slope of the relationship, and the absolute value indicating the strength of the relationship. Because the test only considers the rows of data, it can be used even in cases where some of the data are disapproved. This is an important feature of this test for its application in climatology, because when there are missing values in a data set, a correction to the formula for the variance of $S$ is introduced so that all missing values will be added: 


$$
\operatorname{Var}(S)=\frac{n(n-1)(2 n+5)-\sum_{i=1}^{n} t_{i} i(i-1)(2 i+)}{18}
$$

where $t_{i}$ is the number of links of extent $i$.

Clic-MD allows for selecting the climate elements and agro climatic indices to which the MK trend test is applied and the results of the test are displayed on the screen showing the parameters trend statistics (S), variance (Var), number of cases $(\mathrm{N})$, and standardized $Z$ value ( $Z$ std). If $Z>1.96$, the data series are statistically significant, in other words, a trend exists. A positive value of $Z$ indicates an upward trend and a negative value indicates a downward trend in the data series.

\section{Climatic anomalies and extreme events}

A special graph was made for showing deviations from the average values of weather elements in a selected period with the following characteristics: a) years are plotted along the x-axis; b) on the $y$-axis a horizontal line is placed corresponding to the average temperature or rainfall for the period; $\mathrm{c}$ ) on the $Y$ axis, the bars correspond to values deviating from the average both up and down. Click-MD allows for selection of meteorological variables (for example, Tmax, Tmed, Tmin, and precipitation) and months. Generally, it is observed that the period of change is in the most recent years, but each weather station has its own period of change. A graph of probability of occurrence or Gauss distribution is afterwards made. Stable and change periods are shown in the same figure. The tails on the $x$-axis of the curves indicate the magnitude of extreme events with a probability of occurrence of 0.01 to 0.05 (Beniston 2008).

\section{RESULTS AND DISCUSSION}

The calculation of the annual agro climatic indices is displayed in tables together with the analysis of change trends. When there is an increasing trend, the checkbox will be red and when there is a decreasing trend, the checkbox is blue, allowing for an easy interpretation of numerical results. The length of the growth period can be plotted per year or for time periods and it is possible to select the more convenient type of evapotranspiration for cases (Figure 2). Monthly rainfall bars that lie between the two evapotranspiration lines indicate the months when rain is sufficient for crops, but if the bars are below half of the evapotranspiration value indicate months of insufficient rainfall. Finally, when the line is above potential evapotranspiration there is excess of water and the period is wet. The length of the growth period or months of continuous rain is information of paramount importance in agronomy. In the example shown in Figure 2, the length of the growing period is five months with three months of wet period and seven months of water deficit. With supplemental irrigation water applied during May and November, the growing period could reach up to seven months.

Clic-MD allows for quick automatic calculation of the curve of accumulated precipitation by month in two periods, which allows for inferring changes in rainfall between a reference period and another lapse of time. It is recommended that the period to be compared must be of at least 20 years. Notice that the shape of the curve can be concave in a wet month or convex in a dry. Figure 2 shows an example of increasing rainfall in August during the second period. Data are displayed by clicking on the "show" button. The graphs can be edited, exported as PDF or sent by e-mail.

We recommended starting with summary data to know if there is a changing trend. Once the months in which to evaluate the identified change are selected, it is recommended to use the graphs of increases and decreases for identifying the reference period and the period of change, and afterwards continue with the analysis of anomalies using both the baseline and the change periods (Figure 3 ).

Clic-MD makes possible to identify trends in climate change in sequential increases by correlation analysis or in pulses using the Mann-Kendall test. For example, in the Progreso Yucatán, Mexico, weather station we have identified increases in maximum temperature during May having negative impact on the population. Clic-MD calculates normal distribution graphs for two periods in order to identify in them climate anomalies (in peaks) and extreme events 


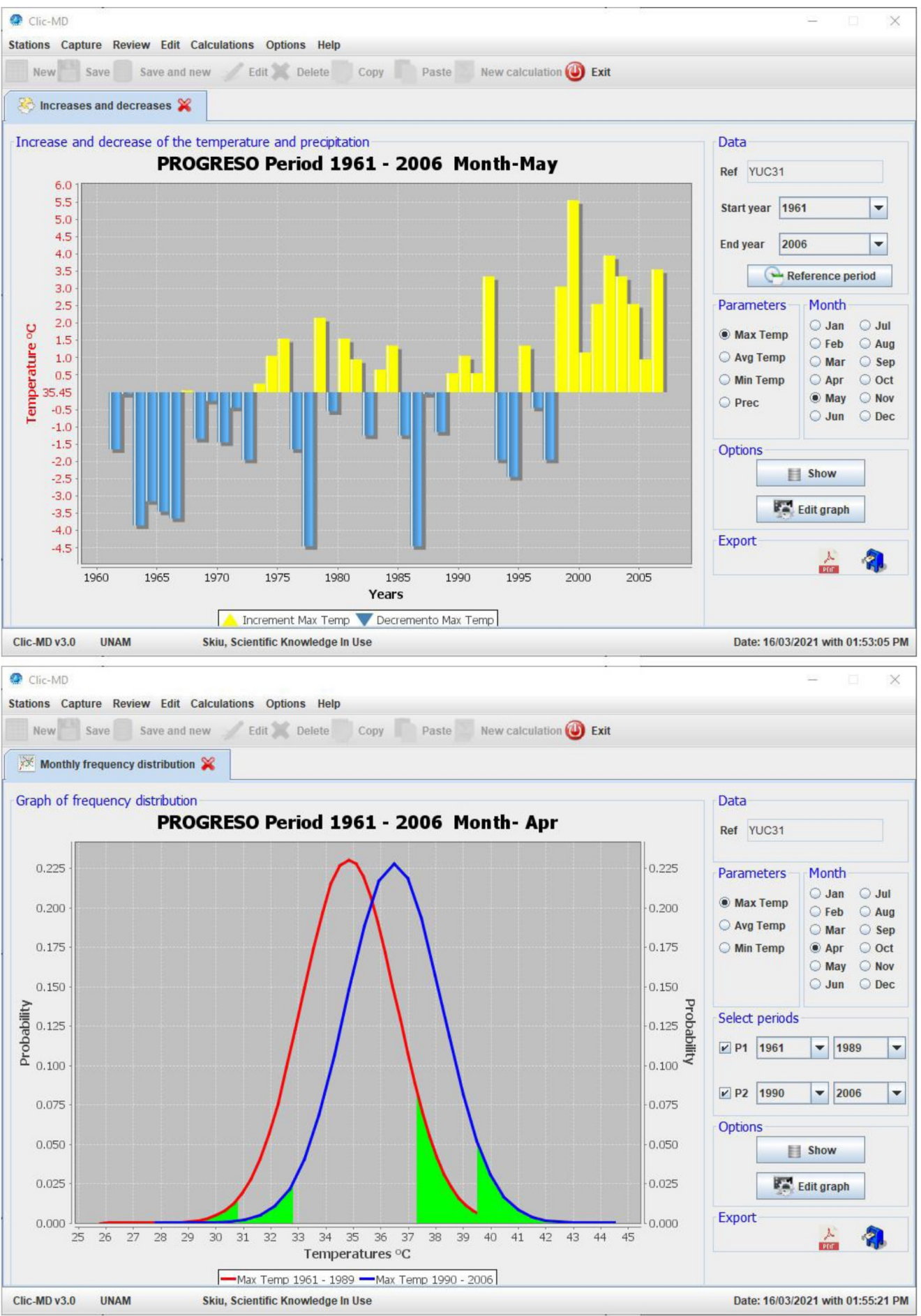

Figure 3. Increase and decrease around mean values and values of extreme temperatures by month.

(in tails), thus making possible to appreciate climate changes. In this example, you can see the displace- ment of extreme values: the red line is the Gauss bell of the reference period and the comparison pe- 
riod is traced in blue (Figure 3). We can see that both the minimum and the maximum values of maximum temperature have shifted towards the right, meaning that the minimum extreme values disappeared, and the maximum extreme values increased. The extreme events in this example increased from 40 to $42^{\circ} \mathrm{C}$, namely a weather anomaly of $2^{\circ} \mathrm{C}$ in higher maximum temperature is displayed.

Clic-MD allows for storing, managing and visualizing thousands of meteorological data in seconds, providing a clear representation of climate trends and extreme events in local and regional settings.

The use of Clic-MD lowers the cost of decisionmaking processes by obtaining accurate data with minimal expenses. For example, a statistics-trained professional would need seven months for analyzing meteorological data from a single weather station using Excel, but the same task can be made in 20 minutes in Clic-MD, displaying 436 graphs from one meteorological station (Figure 4).

Advantages of the use of Clic-MD include:

Clic-MD will allow decision-makers working on affairs related to the anticipation and adaptation to climate change with a more professional, efficient and timely practice. Clic-MD will enable farmers to make accurate diagnosis of adaptation measures dealing with climate change. Clic-MD will allow researches and students to achieve a better working quality and an improved climate data analysis. Clic-MD will provide governmental agencies a better understanding of the problem linked with climate change at the local level, where policy decisions are made.

A large part of Mexico's agricultural land is used for rainfed agriculture, in both, for climates with many dry months (Delgado et al. 2011, Delgado et al. 2017, Montiel-González et al. 2019), and for the scarcity of good quality water aquifers (Delgado et al. 2010). It is for this reason that in recent years, a large number of meteorological stations have been installed throughout the country, which have allowed the analysis of millions of data (Lobit et al. $2018 a, b)$ and also tools have been created for the analysis of these data with agroclimatological objec- tives (Bautista et al. 2019, Montiel et al. 2019, Ortega et al. 2019). This is how this new Clic-MD tool can be used to analyze thousands of data on seconds for agroclimatic purposes.

A rainfed agriculture requires specific climate indicators for the crops, which could be designed with a good knowledge of the physiology of the crops and with a detailed knowledge of the elements of the climate (Ortega et al. 2019), in this sense the Clic-MD software plays an important role. On the other hand, climate change is the most serious global environmental problem, and requires the interaction of inter and trans-disciplinary efforts, where the development of software (Villora et al. 2016), such as Clic-MD, is key for decision-making. Remote and proximal sensors are used to obtain meteorological data (Mendelsohn et al. 2007, Lobit et al. 2018a), so new indexes and software for rapid and precise analysis are being developed (Bautista et al. 2013, Ault et al. 2015, Ortega et al. 2019). The Clic-MD software is yet another tool that allows both agroclimatic analysis and climate change (direction and magnitude).

Clic-MD is a new tool allowing users to organize, store, and process millions of monthly records of temperature and rainfall in seconds. Clic-MD improves estimation of $\mathrm{ET}_{0}$ by using the empirical equations of Hargreaves and Thornwite. The capability of Clic-MD for calculation of agroclimatic indices, length of growth period, and probability of precipitation by month can be used for improving agricultural practices and for reducing human impact on the environmental. The main function of Clic-MD is the agile, quick, and precise identification of monthly and annual climate change trends (direction, magnitude, and period of change). In addition, colored display provides the user of Clic-MD a graphical and numeric representation that is easy to interpret in terms of the significance of the climate change observed in the processed data.

\section{ACKNOWLEDGEMENTS}

Authors acknowledge financial support received from Skiu, www.actswithscience.com 


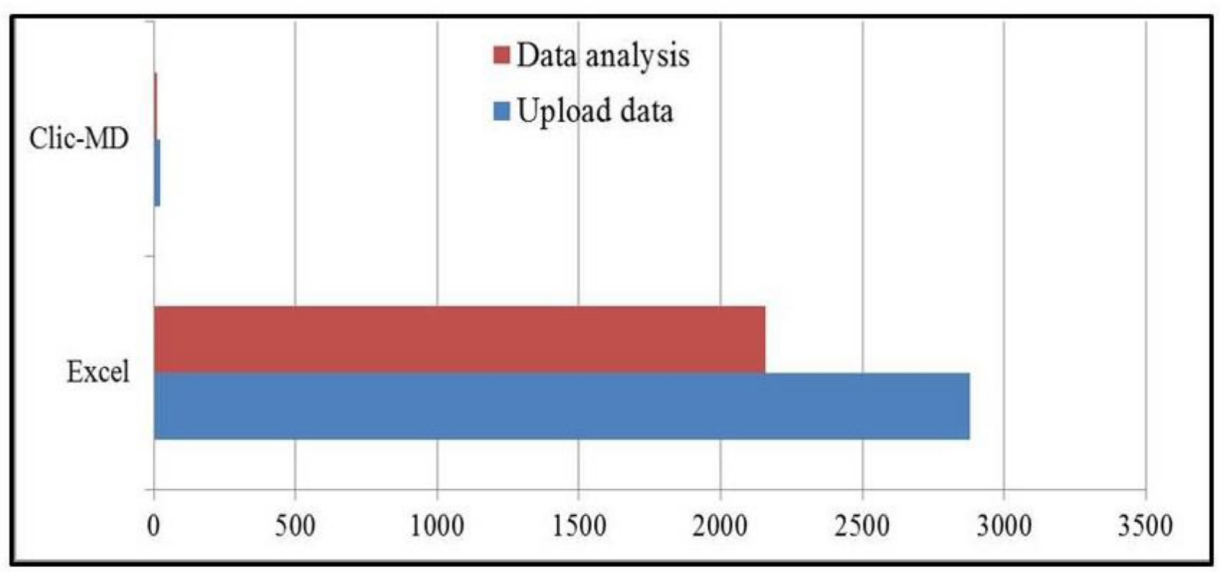

Figure 4. Time in hours needed for analyzing data from one weather station and generating 436 graphics.

\section{LITERATURE CITED}

Allen R, Pereira LS, Raes D, Smith M (1998) Crop evapotranspiration: guidelines for computing crop water requirements. Paper No 56. FAO Irrigation and Drainage. Rome, Italy. 300p.

Archer SR, Predick KI (2008) Climate change and ecosystems of the Southwestern United States. Rangelands 30: 23-28.

Apache Software Foundation! (2014) Apache. Retrieved from (15/04/2021) https://www.apache.org/

Ault TR, Zurita-Milla R, Schwartz MD (2015) A Matlab@ toolbox for calculating spring indices from daily meteorological data. Computers \& Geosciences 83: 46-53.

Bautista F, Bautista-Hernández D, Delgado-Carranza C (2009) Calibration of the equations of Hargreaves and Tornthwaite to estimate the potential evapotranspiration in semi-arid and subhumid tropical climates for regional applications. Atmósfera 22: 331-348.

Bautista F, Bautista-Henandez DA, Álvarez O, De la Rosa D (2013) Software to identified climate change trends at the local level: a study case in Yucatán. Revista Chapingo Serie Ciencias Forestales y del Ambiente 19: 81-90.

Bautista F, Pacheco A, Dubrovina I (2019) Climate change indicators software for computing climate change indices for agriculture. Ecosistemas Recursos Agropecuarios 6: 343-351.

Bautista F, Bautista-Hernández DA, Álvarez O, De la Rosa D (2011) Manual de usuario del sistema de análisis de datos para el monitoreo regional y local del cambio climático con índices agroclimáticos (MOCLIC). Centro de Investigaciones en Geografía Ambiental. Universidad Nacional Autónoma de México. México. 46p.

Bautista F, Pacheco A, Bautista-Hernández DA (2016) Climate change analysis with monthly data (Clic-MD). Software manual. Skiu. México, México. 57p.

Beniston M (2008) Extreme climatic events and their impacts: examples from the Swiss Alps. In: Díaz HFRJ (ed) Murnane, climate extremes and society. Cambridge University Press. New York. USA. pp: 147-164.

Canós J, Letelier P, Penadés M (2003) Metodologías ágiles en el desarrollo de software. En: Patricio LT, Sánchez LE (Ed), Metodologías Ágiles en el Desarrollo de Software. Grupo ISSI. Alicante, España. pp: 1-8.

Carlón T, Mendoza M (2007) Análisis hidrometeorológico de las estaciones de la cuenca del Lago de Cuitzeo. Investigaciones Geográficas 63: 56-76. 
Del Río S, Herrero L, Pinto-Gomes C, Penas A (2011) Spatial analysis of mean temperature trends in Spain over the period 1961-2006. Global and Planetary Change 78: 65-75.

Delgado CC, Pacheco AJ, Cabrera SA, Batllori SE, Orellana R, Bautista F (2010) Quality of groundwater for irrigation in tropical karst environment: the case of Yucatán, México. Agricultural water management 97: 1423-1433.

Delgado CC, Bautista F, Orellana R, Reyes H (2011) Clasificación y zonificación agroclimática utilizando la relación precipitación evapotranspiración en el estado de Yucatán México. Investigaciones Geográficas 75: 51-60.

Delgado C, Bautista F, Ihl T, Palma-López D (2017) Evaluación de la aptitud de tierras para la agricultura de temporal usando la duración del periodo de lluvia en el estado de Yucatán. Ecosistemas y Recursos Agropecuarios 4: 485-497.

Doorenbos J, Pruitt OW (1977) Crop water requirements. FAO Irrigation and Drainage. Paper 24. Land and Water Development Division, FAO. Rome, Italy. 144p.

Eclipse Foundation (2015) IDE Eclipse. Retrieved from (18/11/2014) https://eclipse.org/

FAO (1996) Agro-ecological zoning: Guidelines. Food and Agriculture Organization. FAO Soils Bulletin 73. Soil Resources, Management and Conservation Service, FAO Land and Water Development Division. Rome, Italy.78p.

García M, Raes D, Jacobsen SE, Michel T (2007) Agroclimatic constraints for rainfed agriculture the Bolivian Altiplano. Journal of Arid Environments 71: 109-121.

Hargreaves GH, Samani ZA (1985) Reference crop evapotranspiration from temperature. Applied Engineering in Agriculture 1: 96-99.

Jain SK, Kumar V, Saharia M (2013) Analysis of rainfall and temperature trends in northeast India. International Journal of Climatology 33: 968-978.

Lioubimtseva E, Henebry GM (2009) Climate and environmental change in arid Central Asia: Impacts, vulnerability, and adaptations. Journal of Arid Environments 73: 963-977.

Lobit P, Gómez A, Bautista F, Lhomme JP (2018a) Retrieving air humidity, global solar radiation, and reference evapotranspiration from daily temperatures: development and validation of new methods for Mexico. Part III: reference evapotranspiration. Theoretical and Applied Climatology 133: 799-810.

Lobit P, López Pérez L, Lhomme JP, Gómez A (2018b) Retrieving air humidity, global solar radiation, and reference evapotranspiration from daily temperatures: development and validation of new methods for Mexico. Part I: humidity. Theoretical and Applied Climatology 133: 751-762

López-Diáz F, Conde C, Sánchez O (2013) Analysis of indices of extreme temperature events at Apizaco, Tlaxcala México: 1952-2003. Atmósfera 26: 349-358.

Mendelsohn R, Kurukulasuriya P, Basist A, Kogan F, Williams C (2007) Climate analysis with satellite versus weather station data. Climatic Change 81: 71-83.

Monterroso Al, Gómez JD, Toledo ML, Tinoco JA, Conde C, Gay C (2011) Simulated dynamics of net primary productivity (NPP) for outdoor livestock feeding coefficients driven by climate change scenarios in México. Atmósfera 24: 69-88.

Montiel-González C, Gallegos-Tavera A, Ortega A, Bautista F, Gopar-Merino F, Velázquez A (2019) Análisis climático para la agricultura de temporal en Michoacán, México Ecosistemas y Recursos Agropecuarios 6: 307-316. 
Montiel-González C, Montiel C, Ortega A, Pacheco A, Bautista F (2021) Development and validation of climatic hazard indicators for roselle (Hibiscus sabdariffa L.) crop in dryland agriculture. Ecological Indicators 121: 107-140.

Orellana R, Hernández ME, Espadas C (2011) Ambiente. Clima. En: Bautista F (ed.) Técnicas de muestreo para el manejo de Recursos Naturales. Segunda Edición. CIGA-UNAM. México. pp: 189-225.

Ortega A, Montiel-González C, Gallegos A, Pacheco A, Bautista F (2019) Climatic hazard indicators for rainfed maize in a developing country: the case of Bajo Balsas, Mexico. Nova Scientia 11: 26-52.

Smith M (2000) The application of climatic data for planning and management of sustainable rainfed and irrigated crop production. Agricultural and Forest Meteorology 103: 99-108.

Thom HCS (1958) A note on the gamma distribution. Monthly Weather Review 86: 117-122.

Villers L, Arizpe N, Orellana R, Conde C, Hernández J (2009) Impactos del cambio climático en la floración y desarrollo del fruto del café en Veracruz, México. Interciencia 34: 322-329.

Villoria NB, Elliott J, Müller C, Shin J, Zhao L, Song C, (2016) Rapid aggregation of global gridded crop model outputs to facilitate cross-disciplinary analysis of climate change impacts in agriculture. Environmental Modelling \& Software 75: 193-201. 